\title{
NOTE
}

\section{Root-exuded oxygen in the aquatic angiosperm Ruppia maritima*}

\author{
Glen B. Thursby** \\ Botany Department, University of Rhode Island, Kingston, Rhode Island 02882, USA
}

\begin{abstract}
The potential impact of oxygen from roots on the source of inorganic nitrogen for Ruppia maritima L. (Potamogetonales) was investigated in laboratory experiments. Roots released oxygen at an average rate of 2 to $3 \mu \mathrm{g}$ $\mathrm{O}_{2}$ (mg dry wt $)^{-1} \mathrm{~h}^{-1}$. A distinctive oxygenated zone with a radius of 0.75 to $1.25 \mathrm{~mm}$ developed in the sediment around the roots. Although nitrate and nitrite could have been present in the oxygenated zone, these were unlikely to be significant sources of nitrogen for $R$. maritima. Root hairs extended up to $6 \mathrm{~mm}$ beyond this zone. In addition, roots of plants cultured in a flow-through system took up ammonia at a rate approximately 9 times greater than that for either nitrate or nitrite.
\end{abstract}

Submerged aquatic vascular plants exhibit a variety of adaptations to their environment. In most species large air spaces are continuous throughout the plant (Sculthorpe, 1967; Bristow, 1975). Roots in anaerobic substrates rely on these air spaces for their oxygen supply from the leaves. In emergent and floating leaved plants the source of oxygen is the atmosphere (Teal and Kanwisher, 1966; Dacey, 1980). In submerged species the source of oxygen is photosynthesis (Hartman and Brown, 1967; Oremland and Taylor, 1977). As a result of this oxygen supply to the roots, oxygen can diffuse into the surrounding sediment (Wium-Andersen, 1971; Wium-Andersen and Andersen, 1972; Oremland and Taylor, 1977; Iizumi et al., 1980). This oxygen supports nitrification in anoxic sediment (lizumi et al., 1980). The purpose of this study was to quantify oxygen release from roots of Ruppia maritima (Potamogetonales) and to assess the effect of this oxygen release on the source of inorganic nitrogen available to roots.

- Contribution \#581 of the Environmental Research Laboratory, US Environmental Protection Agency, Narragansett, Rhode Island 02882, USA

- Present address: Environmental Research Laboratory, South Ferry Road, US Environmental Protection Agency, Narragansett, Rhode Island 02882 , USA
Materials and methods. Vegetative Ruppia maritima L. was obtained from flow-through cultures (Thursby, 1983). Each culture chamber had a surface area of $25 \times 35 \mathrm{~cm}$ and a water depth of ca. $8 \mathrm{~cm}$. No nutrients were added to the system, but there was a $5 \mathrm{~cm}$ deep substrate of beach sand. Heated seawater (22 to $24^{\circ} \mathrm{C}$ ) flowed into the chambers at a rate of $125 \mathrm{ml} \mathrm{min}^{-1}$ resulting in a turnover rate of approximately $1 \mathrm{~h}^{-1}$. Light was supplied by cool-white bulbs (100 to $125 \mu \mathrm{E}$ $\mathrm{m}^{-2} \mathrm{~s}^{-1}$ at water suface, on a $16 \mathrm{~h}: 8 \mathrm{~h}$, light: dark cycle). The salinity was $30 \%$.

Root apices of intact plants were isolated inside glass chambers (the upper $4 \mathrm{~cm}$ of screw-capped test tubes)

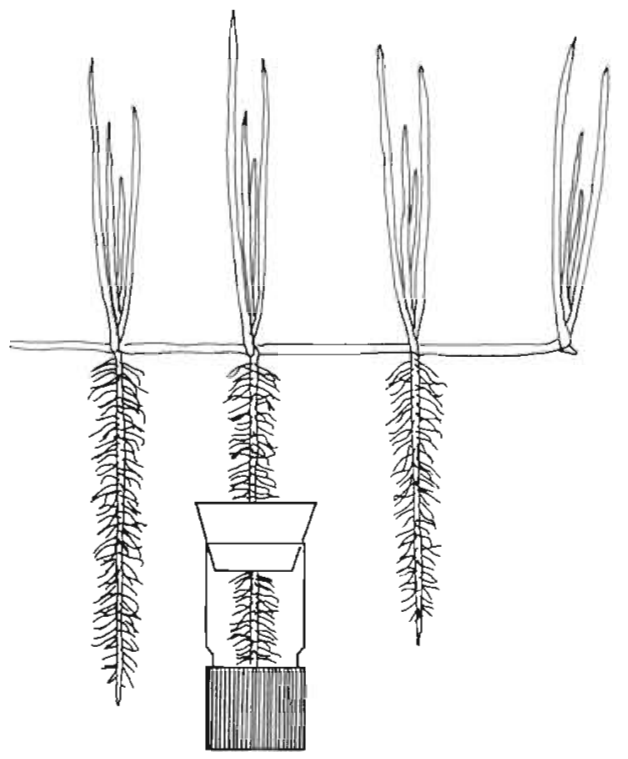

Fig. 1. Diagram of plants and oxygen chamber. Roots were threaded through a hole in a \#00 rubber stopper, and the hole sealed with anhydrous lanolin. The stopper was inserted into the bottom of a cut test tube ( $4 \mathrm{~cm}$ long), the tube filled with seawater, and capped with Parafilm and a screw-cap.

The chamber was darkened with black plastic tape 
darkened with black plastic tape (Fig. 1). Blank chambers (without plants) were tested as controls. Chambers were filled with $0.3 \mu \mathrm{m}$ cartridge-filtered (Balston) ${ }^{*}$ seawater, which had been bubbled with nitrogen gas to reduce oxygen content to either 10 or $50 \%$ of air saturation. Early experiments showed that initial oxygen concentration (at least at $50 \%$ saturation or less) in the water did not affect the release rate of oxygen.

After overnight light or dark pretreatment, plants were incubated for $1 \mathrm{~h}$ in a seawater bath at $30 \%$ salinity at 20 to $22^{\circ} \mathrm{C}$, either at an irradiance of $350 \mu \mathrm{E}$ $\mathrm{m}^{-2} \mathrm{~s}^{-1}$ of daylight fluorescent light or in darkness. Nutrients were added to the seawater at concentrations optimal for static cultures (Thursby, 1983). At the end of the incubation period water samples were removed with a syringe, and oxygen was measured with a blood gas analyzer (Radiometer America, Inc.; Model PHM $71 \mathrm{Mk} 2$ ). Plants were cut at the point of insertion into the stopper, dried $\left(80^{\circ} \mathrm{C}\right)$ and weighed ( $\pm 0.01 \mathrm{mg}$ ).

Measurements of root uptake of ammonia, nitrite and nitrate were performed in 2-compartment chambers to isolate the leaves and roots. These experiments followed procedures previously described (Thursby, 1983). Plants were used either within $1 \mathrm{~h}$ of removal from the flow-through system or incubated overnight with $5 \mu \mathrm{M} \mathrm{NaNO}$ (for nitrate and nitrite uptake), to stimulate nitrate and nitrite reductase activity.

Width of the oxygenated zone (yellow layer) around the roots was measured on an inverted microscope with a calibrated eyepiece micrometer. To produce the oxygenated zone plants were placed into the flowthrough system rooted in $150 \mathrm{ml}$ of anaerobic mud in Pyrex storage dishes. After $2 \mathrm{wk}$ the dishes were removed and the yellow zone measured. Roots were then washed free of sediment and the length of the root hairs recorded.

Results. Evidence for oxygen diffusion out of the roots of Ruppia maritima is shown in Table 1 . Oxygen

Table 1. Ruppia maritima. Oxygen exudation and uptake by roots in darkened chambers (mean $\pm \mathrm{SD}, \mathrm{n}=7$ )

\begin{tabular}{|lcc|}
\hline $\begin{array}{c}\text { Overnight } \\
\text { pretreatment }\end{array}$ & $\begin{array}{c}\mu \mathrm{g} \mathrm{O}_{2}(\mathrm{mg} \mathrm{dry} \text { wt })^{-1} \mathrm{~h}^{-1} \\
\text { Light }\end{array}$ & Dark \\
\hline Light & $+1.97 \pm 1.14$ & $+1.04 \pm 1.08$ \\
Dark & $+2.93 \pm 3.47^{\cdot}$ & $-0.20 \pm 0.91$ \\
Some plants showed a net oxygen removal \\
\hline
\end{tabular}

\footnotetext{
- Use of product tradename does not imply endorsement by the United States Environmental Protection Agency
}

diffused out of the roots when leaves were exposed to the light, and also in the dark, when plants were given a light pretreatment. Net oxygen uptake in the dark by roots was detected only if plants were pretreated overnight in the dark. Roots grown in anaerobic mud developed a distinct oxygenated layer, 0.75 to $1.25 \mathrm{~mm}$ thick $(n=10)$. The appearance of this layer was pale to bright yellow-orange, presumably due to the presence of ferric hydroxide (as suggested by Wium-Andersen and Andersen, 1972; Mendelssohn and Postek, 1982). Root hairs were abundant (ca. $60 \mathrm{~mm}^{-1}$ ), their length ranging from 2.33 to $7.58 \mathrm{~mm}(n=42)$ on mature roots.

Roots of plants used within $1 \mathrm{~h}$ of removal from the flow-through system took up ammonia approximately 9 times faster than either nitrate or nitrite (Table 2). Plants incubated overnight with $5 \mu \mathrm{M}$ nitrate increased their rate of nitrate and nitrite uptake $(20$ and $90 \%$, respectively at $20 \mu \mathrm{M}_{i}$ Fig. 2), but these rates were still less than $25 \%$ of the rate of ammonia uptake by roots.

Table 2. Ruppia maritima. Uptake of inorganic nitrogen by roots (mean \pm S.D., $\mathrm{n}=5$ ). Plants were placed into uptake chambers within $1 \mathrm{~h}$ of their removal from the flow-through system

\begin{tabular}{|ccc|}
$\begin{array}{c}\text { Nitrogen } \\
\text { source }\end{array}$ & $\begin{array}{c}\text { Initial conc. } \\
(\mu \mathrm{M})\end{array}$ & $\begin{array}{c}\text { Uptake rate } \\
\left.\text { (nmol [mg dry wt] }]^{-1} \mathrm{~h}^{-1}\right)\end{array}$ \\
\hline $\mathrm{NO}_{2}$ & 20.6 & $6.9 \pm 1.7$ \\
$\mathrm{NO}_{3}$ & 19.7 & $7.0 \pm 2.5$ \\
$\mathrm{NH}_{4}$ & 20.5 & $60.6 \pm 3.6$ \\
Mean \pm SD & & \\
\hline
\end{tabular}

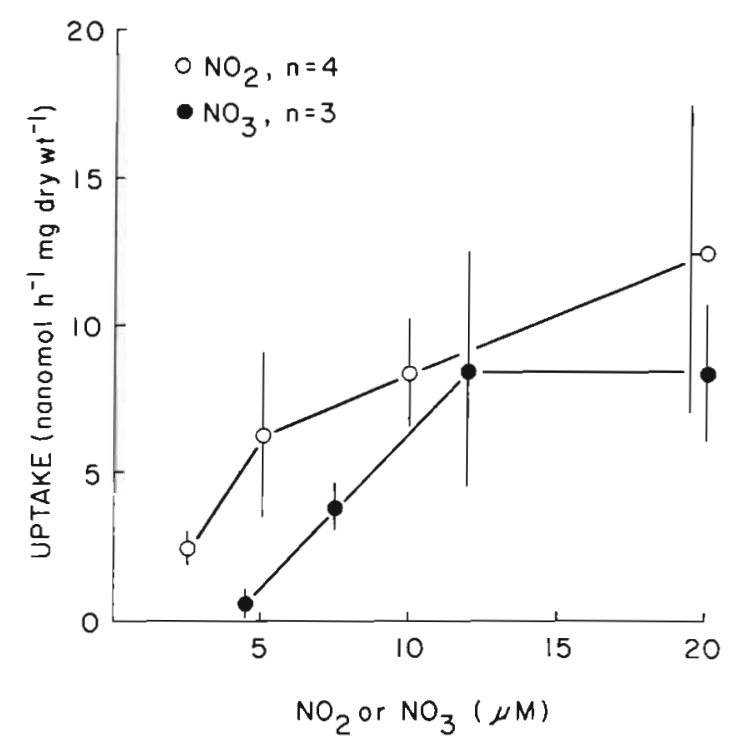

Fig. 2. Uptake rate of nitrate and nitrite by roots of Ruppia maritima as a function of concentration. Prior to experiment, plants were supplied overnight with $5 \mu \mathrm{M}$ of $\mathrm{NaNO}_{3}$. Each point represents the mean $\pm \mathrm{SD}$ 
Discussion. The lacunal system of Ruppia maritima can function as an oxygen reservoir. Roots showed a net removal of oxygen from the water in darkness only when pretreated in the dark. Some roots continued to show a net oxygen release in the dark if the plants were given a light pretreatment. Lacunae of Elodea canadensis and Ceratophyllum demesum also store oxygen (Hartman and Brown, 1967). Oxygen release rates for roots of $R$. maritima were generally less than those reported for freshwater aquatic vascular plants (Armstrong, 1964; 1967), but greater than that for the seagrass Zostera marina (Iizumi et al., 1980).

Nitrification can take place in the rhizosphere, if oxygen is present. Roots of Ruppia maritima plants from the flow-through culture system, however, clearly show greater ammonia uptake than that for either nitrate or nitrite. Ammonia concentrations in interstitial water of marine sediments can exceed $100 \mu \mathrm{M}$ (Hopkinson and Wetzel, 1982; Kenworthy et al., 1982; Iizumi et al., 1982). This is sufficient to saturate ammonia uptake by roots in $R$. maritima (Thursby, 1983). In addition, in the presence of ammonia root uptake of nitrate is negligible (Thursby, 1983). Root hairs of $R$. maritima extended beyond the narrow aerated zone immediately surrounding the roots by as much as $6 \mathrm{~mm}$. Any nitrate or nitrite in the anaerobic sediment would be restricted to the aerated zone. Since root hairs constitute the primary absorptive site in roots (Salisbury and Ross, 1978), the roots may not have ready access to any available nitrate or nitrite.

Oxygen release by roots is more than a result of the necessity of supplying oxygen to the roots. An oxidized layer around the roots of plants in anaerobic substrates can reduce the potential for manganese or iron toxicity, as well as render ethylene, $\mathrm{H}_{2} \mathrm{~S}$ and certain organic acid harmless (Foy et al., 1978; Mendelssohn, 1979). This may serve as the primary function of the oxygenated layer around the roots of Ruppia maritima.

Acknowledgements. I am grateful to Dr. Marilyn M. Harlin, Dr. Luke S. Albert, Dr. Robert G. Sheath, and Dr. Richard J. Hull for helpful comments on this study. I thank Dr. Richard L. Steele for use of facilities at the Environmental Protection Agency laboratory in Narragansett, R. I. and William Nelson for use of the blood gas analyzer.

\section{LITERATURE CITED}

Armstrong, $W$ (1964). Oxygen diffusion from the roots of some British bog plants. Nature, Lond. 204: 801-802
Armstrong, W. (1967). The oxidising activity of roots in waterlogged soils. Physiol. Plant. 20: 920-926

Bristow, J. M. (1975). The structure and function of roots in aquatic vascular plants. In: Torry, J. G., Clarkson, D. T. (ed.) The development and function of roots. Academic Press, New York, p. 221-236

Dacey, J. W. H. (1980). Internal winds in water lilies: an adaptation for life in anaerobic sediments. Science, N. Y. 210: 1017-1019

Foy, C. D., Chaney, R. L., White, M. C. (1978). The physiology of metal toxicity in plants. A. Rev. Pl. Physiol. 29: 511-566

Hartman, R. T., Brown, D. L. (1967). Changes in internal atmosphere of submersed vascular hydrophytes in relation to photosynthesis. Ecology 48: 252-258

Hopkinson, C. S., Wetzel, R. L. (1982). In situ measurements of nutrient and oxygen fluxes in a coastal marine benthic community. Mar. Ecol. Prog. Ser. 10: 29-35

Iizumi, H., Hattori, A., McRoy, C. P. (1980). Nitrate and nitrite in interstitial waters of eelgrass beds in relation to the rhizophere. J. exp. mar. Biol. Ecol. 47: 191-201

Iizumi, H., Hattori, A., McRoy, C. P. (1982). Ammonium regeneration and assimilation in eelgrass (Zostera marina) beds. Mar. Biol. 66: 59-65

Kenworthy, W. J., Zieman, J. C., Thayer, G. W. (1982). Evidence for the influence of seagrasses on the benthic nitrogen cycle in a coastal plain estuary near Beaufort, North Carolina (USA). Oecologia 54: 152-158

Mendelssohn, I. A. (1979). The influence of nitrogen level, form, and application method on the growth response of Spartina alterniflora in North Carolina. Estuaries 2: 106-112

Mendelssohn, I. A., Postek, M. T (1982). Elemental analysis of deposits on the roots of Spartina alterniflora Loisel. Am. J. Bot. 69: 904-912

Oremland, R. S., Taylor, B. F. (1977). Diurnal fluctuation of $\mathrm{O}_{2}$ $\mathrm{N}_{2}$ and $\mathrm{CH}_{4}$ in the rhizophere of Thalassia testudinum Limnol. Oceanogr. 22: 566-570

Salisbury, F. B., Ross, C. W. (1978). Plant physiology, 2nd ed. Wadsworth, California

Sculthorpe, C. D. (1967). The biology of aquatic vascular plants. Amold, London

Thursby, G. B. (1983). Culture-nutrient relations in the aquatic angiosperms Zostera marina L. and Ruppia maritima L. Ph. D. dissertation, University of Rhode Island, Kingston

Teal, J. M., Kanwisher, J. W. (1966). Gas transport in the marsh grass, Spartina alterniflora. J. exp. Bot. 17: 355-361

Wium-Andersen, S. (1971). Photosynthetic uptake of free $\mathrm{CO}_{2}$ by the roots of Lobelia dortmanna. Physiol. Plant. 25: $245-248$

Wium-Andersen, S., Andersen, J. M. (1972). The influence of vegetation on the redox potential of the sediment of Grane Langso, a Danish Lobelia lake. Limnol. Oceanogr. 17 : 948-952

Accepted for printing on January 14, 1984 